\title{
POTENSI IKAN KARANG DI PERAIRAN PESISIR NEGERI HUKURILA, KECAMATAN LEITIMUR SELATAN KOTA AMBON
}

\author{
(Potency of Reef Fish in the Coastal Waters of Hukurila Village, \\ Leitimur Selatan District of Ambon City)
}

\author{
Dicky Sahetapy*, Debby A. J. Selanno dan Novianty Chr. Tuhumury \\ Jurusan Manajemen Sumberdaya Perairan Fakultas Perikanan dan Ilmu Kelautan Universitas Pattimura \\ *dicky_sahetapy@yahoo.com,debby_st@yahoo.co.id,y_louhen@yahoo.com \\ Corresponding author*
}

\begin{abstract}
ABSTRAK: Penelitian dilakukan dari April sampai Mei 2019 di perairan pesisir Negeri Hukurila, Kecamatan Leitimur Selatan Kota Ambon dengan tujuan menganalisis komposisi taksa, diversitas spesies, densitas, sediaan cadang, potensi ikan karang spesies target dan status ikan karang. Data ikan karang dikumpulkan dari 4 stasiun dengan metode underwater visual census (UVC). Ditemukan 192 spesies ikan karang Menempati terumbu karang Hukurila. Famili Pomacentridae, Labridae, Chaetodontidae memiliki kekayaan spesies tinggi, sementara tujuh famili memiliki kekayaan spesies rendah. Diversitas relatif ikan karang di areal studi termasuk kategori miskin hingga moderat, dan diestimasi jumlah spesies ikan karang pada habitat terumbu Negeri Hukurila sebanyak 369 spesies. Diversitas spesies ikan karang tinggi, dengan dominansi spesies rendah dalam komunitas dan keserasian spesies ikan karang dalam kondisi Stabil. Densitas ikan karang antara stasiun terumbu berkisar antara $2.9-4.0 \mathrm{ind} / \mathrm{m}^{2}$. Sediaan cadang ikan karang antara stasiun terumbu berkisar antara $28.840-40.400 \mathrm{ind} / \mathrm{ha}$ dan potensi spesies target berkisar 1,67-5,14 $( \pm 3,53)$ ton/ha terumbu karang. Kondisi ikan karang di terumbu Negeri Hukurila termasuk kategori tinggi.
\end{abstract}

Kata kunci: Ikan karang, keanekaragaman spesies, kepadatan, sediaan cadang, potensi

ABSTRACT: The Study was conducted on April to May 2019 in the coastal waters of Hukurila village, Leitimur Selatan District of Ambon city with the aims to analyzed taxon composition, species diversity, density, standing stock, potency of target species and status of reef fish. Reef fish data were collected at four reef stations using UVC method. The result showed that there were 192 species of reef fish inhabit coral reef of Hukurila village. Pomacentridae, Labridae and Chaetodontidae have high species richness, while other seven families have low species richness. Relative diversity of reef fish in the study area can be classified in poor to moderate category, and the estimated number of species of reef fish was 369 species. Species diversity of reef fish is high, with low species dominance in the community and species evenness of reef fish in their community is in stable condition. Density of reef fish between reef station ranged of 2.9-4.0 ind. $\mathrm{m}^{-2}$. Furthermore, the standing stock of reef fish ranged of 28,840-40,400 ind.ha ${ }^{-1}$ and biomass of target reef fish species ranged of 1.67-5.14 ( \pm 3.53$)$ tons ha ${ }^{-1}$ of coral reefs. Status of reef fish in the coral reef of Hukurila village belong to high category.

Keywords: Reef fish, species diversity, density, standing stock, potency 


\section{PENDAHULUAN}

Posisi Provinsi Maluku sangat strategis karena dipengaruhi oleh Laut Banda, Laut Seram dan laut Arafura, serta mengalami limpasan massa air laut dari Samudera Pacifik dan Samudera Indonesia secara bergantian. Proporsi terbesar perairan laut Provinsi Maluku adalah laut dalam dengan hamparan 1340 pulau, dimana 1336 pulau diantaranya adalah pulau kecil, dan wilayah pesisirnya ditempati ekosistem utama perairan tropis (Sahetapy et al., 2019). Ekosistem terumbu karang sangat dominan kehadirannya di perairan pesisir dengan luas 439.110 ha atau $34.911 \mathrm{~km}^{2}$ (Giyanto dkk., 2017). Kenyataan ini menguatkan posisi Provinsi Maluku yang berada pada Segitiga Terumbu Karang (Green and Mous, 2008; Veron et al., 2009; Muljadi dan Rijoly, 2013; Wouthuyzen et al., 2018). Dengan demikian, perairan Provinsi Maluku memiliki biodiversitas dan potensi sumberdaya hayati laut yang tinggi, terutama sumberdaya ikan karang. Pernyataan ini didukung oleh Bengen (2013) bahwa terumbu karang tersebar di pulau-pulau kecil Indonesia yang berperan penting sebagai habitat bagi beragam spesies ikan, sehingga berdampak pada tingginya produktivitas perikanan (ikan-ikan karang) bernilai ekonomis tinggi.

Sesuai Undang Undang Nomor 1 Tahun 2014, Pulau Ambon termasuk kategori pulau kecil, dengan luas $775 \mathrm{~km}^{2}$. Pulau Ambon terbagi atas dua wilayah administratif dengan luas wilayah Kota Ambon $377 \mathrm{~km}^{2}$ dan $398 \mathrm{~km}^{2}$ lainnya termasuk wilayah Kabupaten Maluku Tengah. Perairan pesisir Kota Ambon berada pada lima wilayah Kecamatan, dengan karakteristik dan keahadiran ekosistem tropis berbeda-beda. Perairan pesisir Kota Ambon memiliki tiga ekosistem utama perairan tropis, yaitu terumbu karang yang dominan (luas), mangrove, dan padang lamun. Perairan pesisir Negeri Hukurila yang termasuk dalam wilayah Kecamatan Leitimur Selatan Kota Ambon, memiliki ekosistem terumbu karang sangat dominan sehingga diyakini memiliki potensi ikan karang yang tinggi pula.

Penelitian ikan di terumbu karang
DOI: https://doi.org/10.30598/TRITONvol15issue2page46-57

Provinsi Maluku telah dilakukan beberapa peneliti, diantaranya biodiversitas ikan karang di Pulau Banda (Halford, 2002), diversitas ikan karang di Kepulauan Banda (Mulyadi dan Rijoly, 2013), perairan pesisir selatan Pulau Ambon (Limmon et al., 2017a), kekayaan spesies ikan karang ekonomis di perairan Pulau Ambon (Limmon et al., 2017b), ikan karang di terumbu Teluk Tuhaha (Sahetapy et al., 2018), ikan konsumsi bernilai ekonomis di terumbu karang Teluk Kotania (Huliselan et al., 2018), potensi ikan karang di terumbu Teluk Tuhaha (Sahetapy et al., 2019), serta penilaian stok ikan karang di sekitar pulau-pulau Laut Banda untuk mendukung mata pencaharian masyarakat lokal (Wouthuyzen et al., 2018). Penelitian ikan karang di pesisir Kecamatan Leitimur Selatan telah dilakukan Rijoly (2006) di terumbu Negeri Rutong dan sekitarnya (termasuk Negeri Hukurila), terumbu Negeri di Leahari (Manuputty, 2008), dan di perairan pesisir selatan Pulau Ambon (Limmon et al., 2017a).

Deskripsi hasil-hasil penelitian di atas menunjukan penelitian ikan karang di perairan pesisir Negeri Hukurila sangat terbatas. Sebaliknya, Pemerintah Kota Ambon berencana mengembangkan pariwisata (termasuk ekowisata bahari) di pesisir dan perairan pesisir Negeri Hukurila, sehinggga data potensi ikan karang menjadi penting untuk disediakan. Oleh karena itu, penelitian ini dilaksanakan dengan tujuan untuk menganalisis komposisi taksa, diversitas spesies, densitas, sediaan cadang, potensi ikan karang spesies target, dan status ikan karang di perairan pesisir Negeri Hukurila.

\section{METODE PENELITIAN}

Penelitian dilakukan di perairan pesisir Negeri Hukurila, Kecamatan Leitimur Selatan, Kota Ambon (Gambar 1) pada bulan April hingga Mei 2019. Data komposisi taksa dan kekayaan spesies, serta jumlah individu ikan karang diperoleh melalui survei pada empat stasiun terumbu karang menggunakan metode Underwater Visual Census (English et al., 1997; Manuputty dan Winardi, 2007; Sahetapy et al., 2018) pada $250 \mathrm{~m}^{2}$ areal transek (50 m panjang, 
$5 \mathrm{~m}$ lebar) yang diletakan pada zona tubir terumbu karang. Ikan karang yang berada dalam $250 \mathrm{~m}^{2}$ areal transek diidentifikasi hingga tingkat spesies mengikuti panduan indentifikasi ikan karang dari Amesbury and Myers (1982), Kuiter (1992), Heemstra and Randall (1993), Lieske and Myers (1995), Allen (2000), Kuiter and Tonozuka (2001), Allen and Steen (2002), Allen et al. (2003), Peristiwady (2006), dan White et al. (2013).

Ikan karang yang teridentifikasi, dikelompokan dalam tiga kategori monev terumbu karang, yaitu ikan karang spesies target, spesies major dan spesies indikator (English et al., 1997; Manuputty dan Winardi, 2007; Sahetapy et al., 2018). Similaritas dan desimilaritas spesies ikan karang antara stasiun terumbu karang dianalisis menggunakan Indeks Similaritas dari Odum (1971).

Total spesies ikan karang pada terumbu karang di perairan pesisir Negeri Hukurila diestimasi menggunakan Coral Fish Diversity Index (CFDI) untuk daerah kecil yang terbatas $\left(<2.000 \mathrm{~km}^{2}\right)$ (Allen, 1998; Allen and Erdmann, 2012), dengan formula Estimasi total spesies $\left(<2.000 \mathrm{~km}^{2}\right)=(3.39 \times \mathrm{CFDI})-20.595$.
Nilai CFDI juga digunakan untuk mengklasifikasi diversitas relatif ikan karang pada habitat terumbu karang Negeri Hukurila (Tabel 1)

Indeks Diversitas Shannonn, Dominansi Simpson dan Keserasian Evenness spesies di dalam komunitas ikan karang dianalisis menggunakan pendekatan dari Odum (1975). Selain itu, penilaian nilai-nilai indeks ekologi komunitas ikan karang mengikuti Hukom (2010) dan Huliselan et al., (2019). Densitas dan Sediaan Cadang (standing stock) ikan karang dihitung mengikuti Amesbury et al. (1982), sementara potensi (biomasa) ikan karang spesies target (ton/ha terumbu karang) yaitu ikan ekonomis penting dan konsumsi dihitung mengikuti Huliselan et al. (2019) dan Sahetapy et al. (2019).

Penilaian status (kondisi) ikan karang pada setiap stasiun (lokasi) terumbu karang di perairan pesisir Negeri Hukurila menggunakan metode dan mengikuti kategori penilaian (Tabel 2) dari Critic COREMAP (2005), Hukom dan Retraubun (2008), serta Hukom (2010).

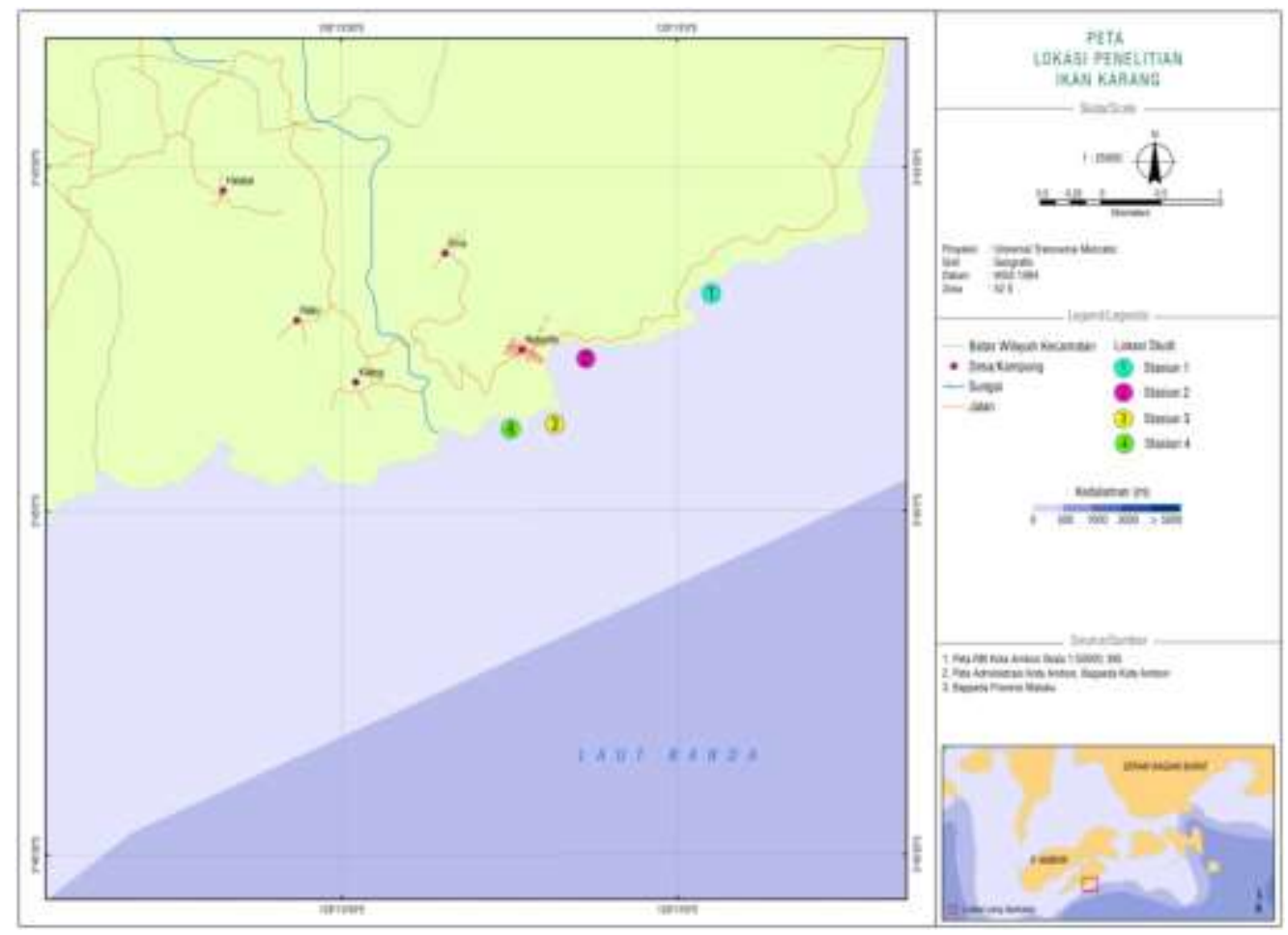

Gambar 1. Peta Lokasi Penelitian ikan karang di perairan pesisir Negeri Hukurila 
DOI: https://doi.org/10.30598/TRITONvol15issue2page46-57

Table 1. Diversitas relatif ikan karang yang didasarkan pada nilai CFDI

\begin{tabular}{lccc}
\hline \multirow{2}{*}{ Kategori } & \multicolumn{3}{c}{ CFDI Value } \\
\cline { 2 - 4 } & Lokasi Sampling & Region Lokal & Region National \\
\hline Extraordinary & $>150$ & $>330$ & $>400$ \\
Excellent & $130-149$ & $260-329$ & $330-339$ \\
Good & $100-129$ & $200-259$ & $220-239$ \\
Moderate & $70-99$ & $140-199$ & $160-219$ \\
Poor & $40-68$ & $50-139$ & $80-159$ \\
Very Poor & $<40$ & $<50$ & $<80$ \\
\hline
\end{tabular}

Table 2. Enam parameter penilaian status (kondisi) ikan karang

\begin{tabular}{lrrr}
\hline \multirow{2}{*}{ Parameter Penilaian } & \multicolumn{3}{c}{ Kategori Penilaian } \\
\cline { 2 - 4 } & \multicolumn{1}{c}{ Low } & \multicolumn{1}{c}{ Moderate } & \multicolumn{1}{c}{ High } \\
& $1-250$ & \multicolumn{1}{c}{$(4)$} & \multicolumn{1}{c}{$6)$} \\
\hline Total Kelimpahan Ikan (TKI): individu & $1-10$ & $11-30$ & $>1000$ \\
Total Kelimpahan Ikan Chaetodontidae (TKIC) & $1-30$ & $31-100$ & $>100$ \\
Total Kelimpahan Spesies Target (TKST): ind. & $1-210$ & $211-870$ & $>870$ \\
Total Kelimpahan Spesies Major (TKSM): ind. & $1-15$ & $16-60$ & $>60$ \\
Total Jml. Spesies Ikan Karang (TJSIK): jml. sp & $1-3$ & $4-10$ & $>10$ \\
Jml. Species Ikan Chaetodontidae (JSIC): jml. sp & $1-19$ & $20-31$ & $>31$ \\
\hline Nilai Komulatif & &
\end{tabular}

\section{HASIL DAN PEMBAHASAN}

\section{Komposisi Taksa Ikan Karang}

Berdasarkan hasil penelitian, teridentifikasi 192 spesies ikan karang dari 78 genera dan 26 famili (Gambar 2) yang menempati habitat terumbu karang Negeri Hukurila Kekayaan spesies ikan karang yang diperoleh lebih tinggi jika dibandingkan dengan hasil penelitian sebelumnya yaitu sebesar 59 spesies ikan karang di Negeri Hukurila (Rijoly, 2006); Limmon et al. 2017a). Kekayaan spesies ikan karang yang diperoleh juga lebih tinggi dibandingkan pada terumbu karang Negeri Rutong yaitu sebanyak 67 spesies (Rijoly, 2006).

Ditemukan lima famili ikan karang dengan kekayaan spesies tinggi, yaitu Pomacentridae (44 jenis), Labridae (27 jenis), Chaetodontidae (18 jenis), Serranidae dan Acanthuridae masing-masing 15 spesies. Sebaliknya, tujuh famili ikan karang memiliki kekayaan spesies rendah (hanya 1 spesies), yaitu Aulostomidae, Bleniidae, Kyphosidae,
Monacanthidae, Phempherididae, Tetraodontidae, Zanclidae. Kekayaan spesies yang ditemukan pada kelima family ikan karang tersebut merupakan hal yang umum ditemukan dalam ekosistem terumbu karang (Sahetapy et al., 2018). Tiga dari lima famili ikan karang dengan kekayaan spesies tinggi, yaitu Pomacentridae, Labridae dan Chaetodontidae adalah penghuni permanen terumbu karang (Allen, 1998; Chou, 2000) dan termasuk dalam sepuluh famili ikan karang paling spesifik pada terumbu karang Indonesia (Allen and Adrim, 2003). Menurut Chou (2000), sebanyak 123 spesies ikan karang dari famili Pomacentridae mendiami terumbu karang di wilayah Indonesia Timur. Berbasis hasil analisis, terdapat $35,8 \%$ spesies ikan dari famili Pomacentridae di wilayah Indonesia Timur yang menempati terumbu karang di Negeri Hukurila. Diantara 44 spesies ikan karang dari famili Pomacentridae yang ditemukan, ternyata Neoglyphidodon crossi merupakan spesies endemik. Jumlah spesies ikan famili Pomacentridae di terumbu 
karang Negeri Hukurila (44 spesies) lebih tinggi dibandingkan yang diperoleh sebanyak 12 spesies di terumbu karang Negeri Rutong (Rijoly, 2006) dan 21 spesies di terumbu karang Negeri Leahari (Manuputty, 2008).

Terumbu karang Indonesia memiliki 178 spesies ikan famili Labridae (Allen and Adrim, 2003), sementara Muljadi dan Rijoly (2013) memperoleh 61 spesies ikan famili Labridae di terumbu karang Kepulauan Banda, dan 39 spesies dari famili Labridae di terumbu karang Teluk Tuhaha (Sahetapy et al, 2018). Merujuk pada hasil-hasil penelitian tersebut, spesies ikan karang famili Labridae di terumbu Indonesia sekitar 15,2\%, 44,3\% di terumbu karang Kepulauan Banda, dan 69,2\% di terumbu karang Teluk Tuhaha, sedangkan pada terumbu karang Negeri Hukurila ditermukan 27 spesies. Terdapat satu spesies ikan karang tergolong spesies endemik, yaitu Cirrhilabrus solorensis diantara 27 spesies ikan famili Labridae yang ditermukan tersebut. Kekayaan spesies ikan famili Labridae di terumbu karang Negeri Hukurila lebih tinggi dari 11 spesies jika dibandingkan di terumbu karang Negeri Rutong (Rijoly, 2006), dan 24 spesies di terumbu karang Negeri Leahari (Manuputty, 2008).

Terumbu karang Indonesia memiliki 59 spesies ikan famili Chaetodontidae (Allen and Adrim, 2003), sementara terumbu karang
Kepulauan Banda memiliki 32 spesies ikan famili Chaetodontidae (Muljadi dan Rijoly, 2013), dan 23 spesies ikan famili Chaetodontidae di terumbu karang Teluk Tuhaha (Sahetapy et al., 2018). Berbasis data tersebut, berturut-turut $30,5 \%, 56,3 \%$ dan $78,3 \%$ spesies ikan famili Chaetodontidae di terumbu karang Indonesia, Kepulauan Banda dan Teluk Tuhaha ditemukan di terumbu karang Negeri Hukurila. Jumlah spesies ikan famili Chaetodontidae yang ditemukan (18 spesies) lebih tinggi dari 8 spesies di terumbu Negeri Rutong (Rijoly, 2006), dan 14 spesies di terumbu karang Negeri Leahari (Manuputty, 2008).

Kekayaan spesies dan genera ikan karang di terumbu karang stasiun 4 (ST4) lebih tinggi dibanding tiga Stasiun terumbu karang yang lain (Gambar 2). Sekitar $71 \%$ spesies ikan di terumbu karang pada lokasi penelitian dapat ditemukan di ST4. Selain itu, kekayaan famili ikan karang di terumbu karang ST1 dan ST3 relatif lebih tinggi dibanding terumbu ST2 dan ST4, tetapi kekayaan spesies ikan karang pada ST3 lebih rendah dari ST2 dan ST4. Kondisi ini disebabkan oleh variasi spesies ikan karang dari famili Pomacentridae yang tinggi di terumbu karang ST2 dan ST4.

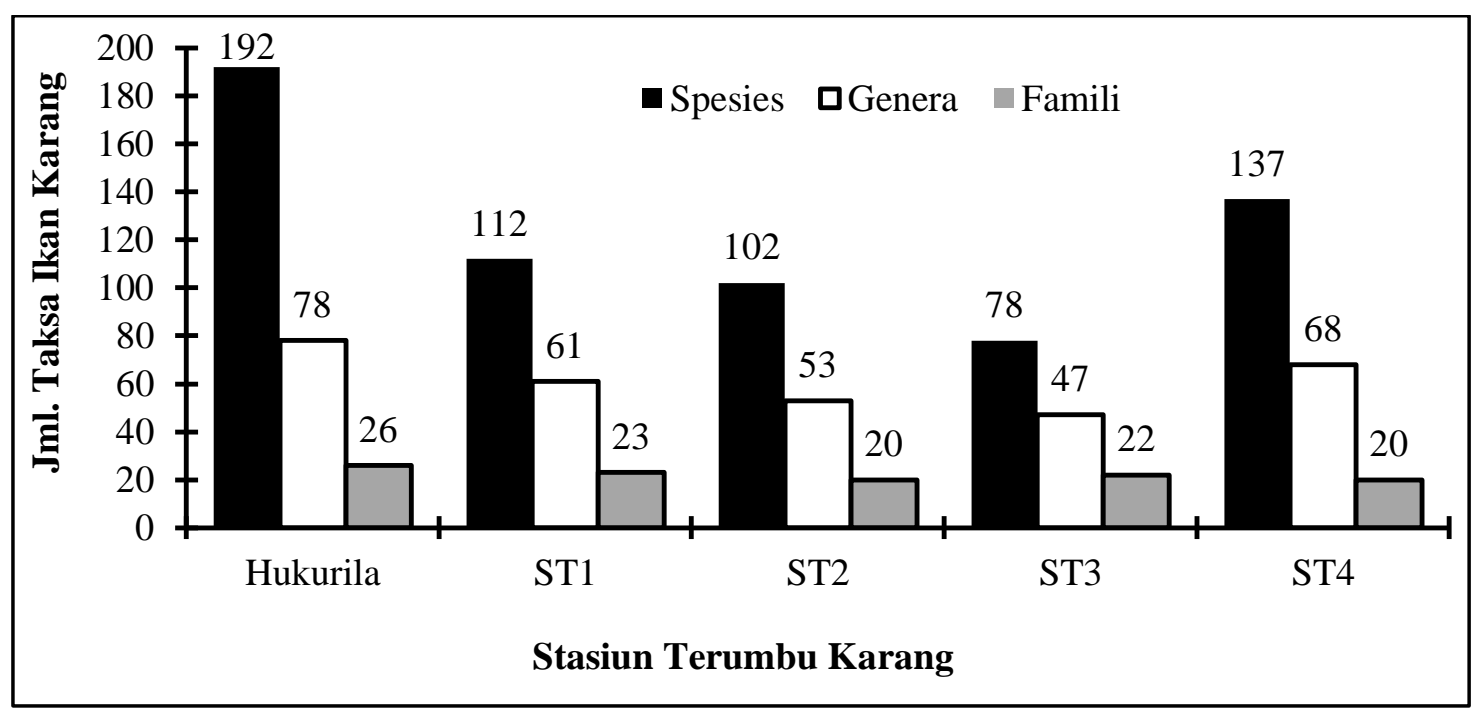

Gambar 2. Fluktuasi jumlah taksa ikan karang di terumbu karang Negeri Hukurila 
Nilai Indeks Kesamaan Spesies (S) ikan karang antar stasiun berkisar antara 0,50-0,66 (50\%-66\%). Kesamaan spesies ikan karang antara terumbu ST1 dan ST2 mencapai 0,66 (66\%), sementara antara ST1 dan ST3 sebesar $0,50(50 \%)$. Hasil ini mengindikasikan bahwa terdapat ketidaksamaan (desimilaritas) spesies ikan karang antar stasiun terumbu sebasar 0,340,50 (34-50\%). Ketidaksamaan spesies ikan karang ini disebabkan oleh $34-50 \%$ spesies ikan karang memiliki mikrohabitat spesifik pada salah satu lokasi terumbu dan spesies-spesies ikan karang tersebut tidak hidup pada lokasi terumbu karang yang lain.

Mengacu pada kriteria monev terumbu karang (English et al, 1997; Manuputty dan Winardi, 2007; Sehetapy et al., 2018), maka terumbu karang yang diteliti memiliki 103 spesies ikan karang kriteria spesies major, 71 spesies target dan 18 spesies indikator (Gambar 3). Kekayaan spesies ikan karang ini lebih rendah dari hasil penelitian Limmon et al, (2017a) yang memperoleh 83 spesies target, 183 spesies major dan 27 spesies indikator di terumbu karang perairan pesisir selatan Pulau Ambon. Terumbu karang yang diteliti memiliki kekayaan ikan karang spesies indikator (famili Chaetodontidae) relatif rendah yang mengindikasikan bahwa terumbu karang Negeri

DOI: https://doi.org/10.30598/TRITONvol15issue2page46-57

Hukurila berada dalam kondisi kurang sehat. Kenyataan ini diduga disebabkan oleh beberapa faktor, diantaranya tekanan lingkungan alam, kondisi terumbu atau tekanan pemanfaatan terumbu karang.

Sebaran hasil analisis menunjukan jumlah spesies ikan karang kategori spesies target, major dan indikator di terumbu karang ST4 lebih tinggi dari tiga stasiun lainnya, terutama terumbu karang ST3. Jumlah spesies ikan karang kategori spesies major lebih tinggi dari spesies target dan terutama spesies indikator pada keempat stasiun terumbu karang (Gambar 3). Hal ini menunjukkan kondisi alamiah pada suatu ekosistem terumbu karang bahwa kekayaan spesies ikan karang kategori spesies major selalu lebih tinggi dari spesies target dan terutama spesies indikator. Terumbu karang ST4 memiliki kekayaan spesies ikan karang kategori spesies indikator yang tinggi, dimana $83 \%$ dari spesies ikan famili Chaetodonntidae di terumbu karang Negeri Hukurila dapat ditemukan di areal terumbu karang ST4. Kekayaan spesies ikan karang kategori spesies indikator ini mengindikasikan bahwa terumbu karang ST4 berada dalam kondisi relatif baik atau sehat (English et al., 1997; Manuputty dan Winardi, 2007; dan Sahetapy et al., 2018).

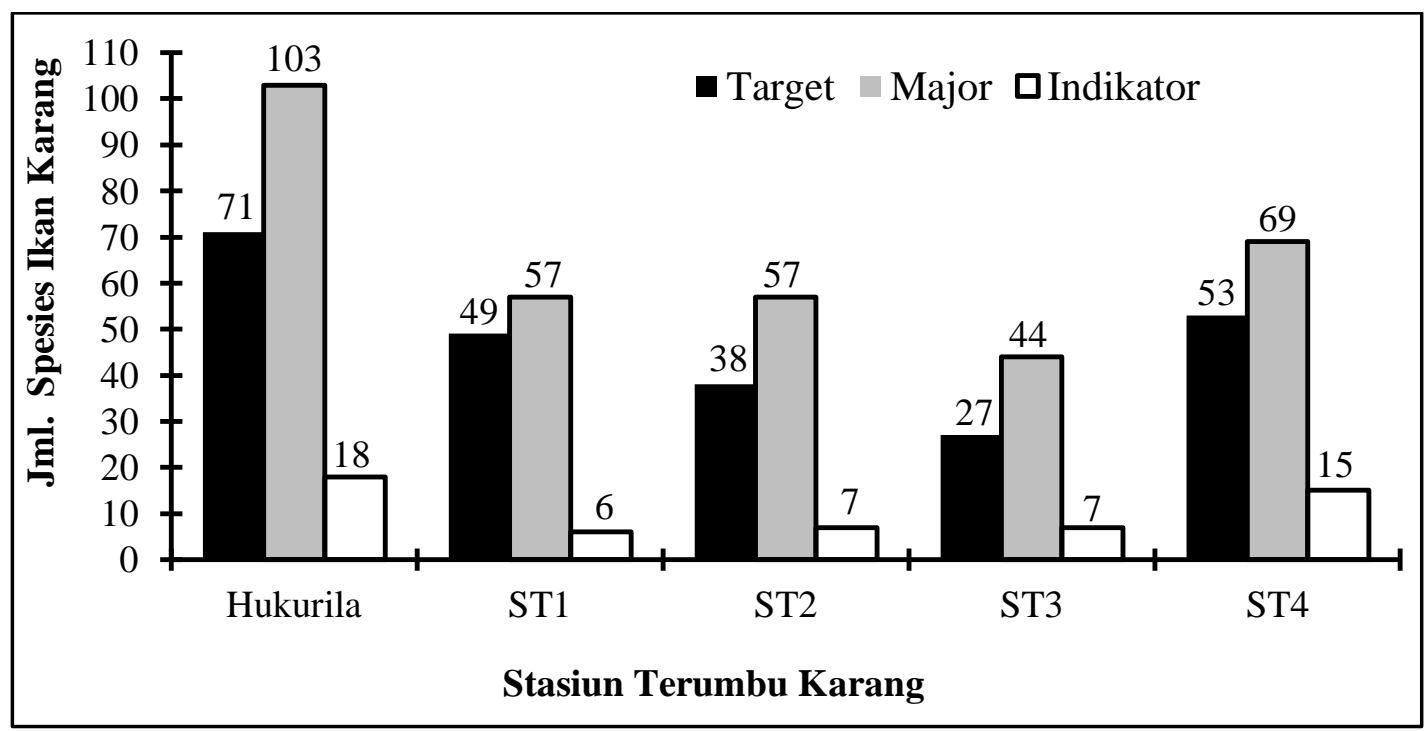

Gambar 3. Fluktuasi jumlah spesies ikan karang menurut kriteria Monev terumbu 
Hasil analisis menunjukan 35 spesies ikan karang tergolong menyebar luas pada keempat stasiun terumbu karang. Sebaliknya, 56 spesies ikan karang menyebar terbatas karena rentan terhadap tekanan pemanfaatan khususnya pada ST3 yang berada dekat dengan pemukiman sehingga populasinya menurun serta mikro habitatnya berubah. Jumlah spesies ikan karang yang menyebar terbatas pada ST4 sebesar 22 jenis, ST3 sebesar 12 jenis, ST1 dan ST2 masing-masing 8 spesies ikan karang.

\section{Diversitas Relatif Ikan Karang}

Secara keseluruhan, nilai CFDI ikan karang (Tabel 3) pada habitat terumbu karang Negeri Hukurila adalah 115, yang termasuk dalam kategori poor atau miskin (lihat Tabel 1 untuk kriteria). Nilai CFDI berkisar antara 4486 (miskin-moderat). CFDI digunakan untuk menentukan diversitas relatif ikan karang yang berbasis pada jumlah spesies dari enam famili ikan karang utama atau famili indikator, yaitu Chaetodontidae, Pomacanthidae, Pomacentridae, Labridae, Scaridae, dan Acanthuridae (Limmon et al., 2017a; Sahetapy et al., 2018).

Jumlah spesies ikan karang yang ditemukan sebesar 192 spesies (Tabel 3), sementara jumlah spesies ikan karang hasil estimasi berbasis nilai CFDI dari enam famili utama atau indikator adalah 369 spesies. Nilai estimasi menunjukkan jumlah spesies ikan karang yang ditemukan seharusnya 177 spesies (48\%) lebih banyak dari jumlah spesies ikan yang ditemukan di habitat terumbu karang Negeri Hukurila. Dalam hal ini, lebih banyak spesies ikan karang dapat ditemukan di terumbu karang Negeri Hukurila jika pengumpulan data dilakukan berulang kali (Limmon et al., 2017a; Sahetapy et al., 2018). Nilai CFDI ikan karang pada lokasi penelitian (115) lebih tinggi dari yang ditemukan di terumbu karang Seram Barat yaitu sebesar 93 (Rijoly, 2015). Namun demikian, nilai CFDI ikan karang di terumbu karang Negeri Hukurila dengan nilai CFDI sebesar 167 di terumbu karang Maluku Tengah dan 158 di terumbu karang Pulau Buru (Rijoly, 2015), nilai CFDI 165 di perairan pesisir selatan Pulau Ambon (Limmon et al., 2017a), dan CFDI ikan karang sebesar 138 di terumbu karang Teluk Tuhaha, Pulau Saparua (Sahetapy et al., 2018).

\section{Indeks Ekologi Komunitas Ikan Karang}

Berbasis hasil analisis dan kriteria penilaian (Hukom, 2010; Huliselan et al., 2019), maka indeks Keragaman spesies ikan karang antar stasiun terumbu dan total terumbu karang (Tabel 4) termasuk kriteria tinggi $\left(\mathrm{H}^{\prime}>3,0\right)$. Kenyataan sebaliknya, indeks Dominansi spesies ikan karang termasuk kriteria rendah, dan nilai indeks keserasian spesies termasuk kategori Tinggi. Jumlah spesies ikan karang kategori jarang (1-2 individu) memberi kontribusi yang besar terhadap Keragaman spesies ikan karang dalam komunitasnya. Selain itu, spesies ikan karang yang dominan (1-4 spesies) memberi kontribusi yang kecil terhadap dominansi spesies ikan karang dalam komunitasnya pada tiap stasiun terumbu karang. Berdasarkan hasil analisis dan kriteria tersebut, maka spesies ikan karang dalam komunitas pada empat stasiun terumbu karang berada dalam kondisi berimbang (steady state).

Table 3. Nilai CFDI, jumlah spesies dan kategori ikan karang

\begin{tabular}{ccccc}
\hline Stasiun & CFDI & Spesies Terobservasi & Estimasi spesies & Kategori \\
\hline 1 & 64 & 112 & 196 & Poor \\
2 & 70 & 102 & 213 & Moderate \\
3 & 44 & 78 & 129 & Poor \\
4 & 86 & 137 & 271 & Moderate \\
\hline Total & 115 & 192 & 369 & Poor \\
\hline
\end{tabular}


Selain itu, jika data hasil analisis (Tabel 4) dihubungkan dengan kriteria penilaian Hukom, 2010), maka komunitas ikan karang pada empat stasiun terumbu karang berada dalam kondisi stabil. Huliselan et al, (2019) mengatakan bahwa secara umum komunitas ikan karang spesies target di terumbu karang Teluk Kotania Bagian Dalam memiliki keragaman spesies yang tinggi dengan dominansi spesies rendah, serta nilai indeks keserasian spesies stabil dan berada dalam kondisi berimbang. Sehingga dapat dikatakan bahwa keragaman spesies ikan karang di terumbu karang Negeri Hukurila tergolong tinggi, dengan dominansi spesies yang rendah di dalam komunitas, keserasian spesies ikan karang dalam komunitas berimbang, dan komunitas ikan karang berada dalam kondisi stabil.

\section{Estimasi Potensi Ikan Karang}

Densitas ikan karang antar stasiun terumbu karang termasuk kriteria rendah hingga tinggi (Tabel 5). Densitas ikan karang ini relatif rendah dari terumbu karang Negeri Hukurila tahun 2006 (Rijoly, 2006) yaitu 6,5 ind $/ \mathrm{m}^{2}$, terumbu karang Negeri Leahari (Manuputty,
2008) yaitu 3,3 - $5,0 \mathrm{ind} / \mathrm{m}^{2}$, dan terumbu karang Negeri Rutong sebesar $11,5 \mathrm{ind} / \mathrm{m}^{2}$ (Rijoly, 2006). Densitas ikan karang pada terumbu ST4, ST1 dan ST2 termasuk kriteria tinggi, tetapi rendah di terumbu ST3 yang disebabkan oleh beberapa spesies ikan major yang umumnya hidup bergerombol (populasi besar), seperti spesies Amblyglyphidodon curacao, Abudefduf sexfasciatus, Chromis margaritifer dan Cirrhilabrus cyanopleura dengan kelimpahan individu yang rendah. Selain itu, Chromis atripectoralis dan Chromis viridis yang umumnya hidup bergerombol, ternyata tidak ditemukan di terumbu karang ST3.

Secara umum nilai sediaan cadang (standing stock) ikan karang termasuk kriteria sedang. Nilai sediaan cadang ikan karang yang diperoleh Rijoly (2006) di terumbu karang Negeri Hukurila (65.360 ind/ha) lebih tinggi dari hasil penelitian ini (34.203 ind/ha). Rendahnya nilai sediaan cadang ikan karang tersebut disebabkan oleh pupulasi ikan karang spesies target dan spesies major pada terumbu karang keempat stasiun penelitian ini telah menurun dalam kurun waktu 13 tahun.

Tabel 4. Nilai-nilai indeks ekologi komunitas ikan karang antara terumbu karang

\begin{tabular}{ccccccc}
\hline $\begin{array}{c}\text { Stasiun } \\
\text { Terumbu }\end{array}$ & \multicolumn{2}{c}{ Indeks Shannon } & \multicolumn{2}{c}{ Indeks Simpson } & \multicolumn{2}{c}{ Indeks Evenness } \\
Kriteria & D & Kriteria & E & Kriteria \\
\hline ST1 & 3,91 & Tinggi & 0,034 & Rendah & 0,83 & Stabil \\
ST2 & 3,92 & Tinggi & 0,035 & Rendah & 0,84 & Stabil \\
ST3 & 3,58 & Tinggi & 0,055 & Rendah & 0,81 & Stabil \\
ST4 & 3,91 & Tinggi & 0,041 & Rendah & 0,81 & Stabil \\
\hline Hukurila & 3.97 & Tinggi & 0,017 & Rendah & 0,82 & Stabil \\
\hline
\end{tabular}

Tabel 5. Densitas, Sediaan Cadang (SC) dan Potensi (biomas) ikan karang

\begin{tabular}{ccccccc}
\hline $\begin{array}{c}\text { Stasiun } \\
\text { Terumbu }\end{array}$ & $\begin{array}{c}\text { Densitas } \\
\text { (ind/m } \mathbf{m}^{\mathbf{2}} \text { ) }\end{array}$ & $\begin{array}{c}\text { Stan.Stock } \\
\text { (ind/ha) }\end{array}$ & $\begin{array}{c}\text { Potensi } \\
\text { (ton/ha) }\end{array}$ & $\begin{array}{c}\text { Kriteria } \\
\text { Densitas }\end{array}$ & $\begin{array}{c}\text { Kriteria } \\
\text { SS }\end{array}$ & $\begin{array}{c}\text { Kriteria } \\
\text { Potensi }\end{array}$ \\
\hline ST1 & 3.6 & 35.568 & 4.18 & Sedang & Sedang & Tinggi \\
ST2 & 3.4 & 34.080 & 3.49 & Sedang & Sedang & Sedang \\
ST3 & 2.9 & 28.840 & 1.67 & Rendah & Randah & Rendah \\
ST4 & 4.0 & 40.400 & 5.14 & Tinggi & Tinggi & Tinggi \\
\hline Hukurila & 3.4 & 34.203 & 3.53 & Sedang & Sedang & Sedang \\
\hline
\end{tabular}


Secara spesial, sediaan cadang ikan karang di terumbu karang ST4 termasuk kriteria tinggi dibandingkan ST3 yang rendah (Tabel 5). Sediaan cadang ikan karang yang tinggi di terumbu ST4 ini karena kehadiran lima spesies ikan dengan kelimpahan individu tinggi yaitu Pterocaesio tile, Caesio caerulaureus, C. teres, Odonus niger, Naso thynoides (spesies target). Nilai sediaan cadang ikan karang di terumbu karang ST1 dan ST2 termasuk kriteria sedang, sedangkan pada ST3 termasuk kategori rendah karena rendahya kelimpahan individu ikan karang spesies target maupun species major. Secara keseluruhan, spesies ikan karang dengan nilai sediaan cadang tinggi di terumbu karang Negeri Hukurila adalah Pterocaesio tile, Odonus niger, Caesio teres, C. caerulaureus, Naso thynoides (spesies target), serta Chromis ternatensis dan Pseudanthias huchti (spesies major). Ketujuh spesies ikan karang dengan nilai sediaan cadang tinggi tersebut umumnya hidup bergerombol, dengan populasi relatif besar dan hidup di zona tepi tubir hingga zona tubir terumbu (Kuiter and Tanozuka, 2001; Allen et al, 2003).

Potensi (biomasa) ikan konsumsi dan ekonomis penting (spesies target) termasuk kriteria sedang, tetapi lebih besar dari hasil penelitian Rijoly (2006) yaitu sebesar 2,01 ton/ha terumbu karang Negeri Hukurila. Secara spasial, potensi ikan karang spesies target di terumbu karang ST4 dan ST1 termasuk kriteria tinggi, sementara pada terumbu karang ST3 termasuk kriteria rendah (Tabel 5). Fakta ini disebabkan terumbu karang ST3 memiliki densitas dan nilai sediaan cadang ikan karang spesies target yang rendah.

Berbasis hasil analisis (Tabel 5), secara spasial potensi lestari (MSY), dan jumlah tangkapan ikan karang spesies target yang diperbolehkan (JTB) dapat dirinci sebagai berikut: MSY pada ST4 sebesar 1,94 ton/ha dan JTB 1,55 ton/ha, MSY $\pm 1,58$ ton/ha dan JTB \pm 1,26 ton/ha pada terumbu karang ST1, MSY \pm 1,37 ton/ha dan JTB $\pm 1,1$ ton/ha pada terumbu karang ST2, dan MSY $\pm 0,62$ ton/ha dengan JTB hanya 0,49 ton/ha pada terumbu karang ST3. Nilai JTB ikan karang spesies target di terumbu ST4 dan ST1 menunjukan adanya kegiatan pemanfaatan dengan menggunakan alat tangkap yang ramah lingkungan, seperti Pancing Ulur. Nilai JTB yang rendah pada ST3 menunjukan tidak ada pemanfaatan sumberdaya ikan karang spesies target.

Jika uraian nilai denditas, sediaan cadang dan potensi ikan karang yang diperoleh dihubungkan dengan teori ekologi ikan karang (Lowe-MacConnell, 1987), maka spesies ikan karang dengan nilai densitas, sediaan cadang dan potensi kriteria rendah berpotensi meninggalkan terumbu karang ST3 karena kalah dalam kompetisi terhadap ruang dan makanan dengan spesies ikan karang yang memiliki densitas, sediaan cadang dan potensi kriteria sedang atau tinggi. Selain itu, spesies ikan karang pada terumbu karang ST3 akan hilang jika terdapat tekanan lingkungan, terutama tekanan pemanfaatan ikan karang konsumsi dan ekonomis penting pada lokasi terumbu karang ini.

Tabel 6. Status (kondisi) ikan karang antar areal terumbu krarang Negeri Hukurila

\begin{tabular}{lcccc}
\hline \multirow{2}{*}{\multicolumn{1}{c}{ Parameter Penilaian }} & \multicolumn{3}{c}{ Areal Terumbu Karang } \\
\cline { 2 - 5 } & ST1 & ST2 & ST3 & ST4 \\
\hline Total Kelimpahan Ikan & $1800(6)$ & $1705(6)$ & $1450(6)$ & $2020(6)$ \\
Total Kelimpahan Spesies Tatget & $836(6)$ & $698(6)$ & $335(6)$ & $1028(6)$ \\
Total Kelimpahan Spesies Major & $900(6)$ & $962(6)$ & $1076(6)$ & $902(6)$ \\
Total Kelimpahan Ikan Chaetodontidae & $44(6)$ & $44(6)$ & $32(6)$ & $90(6)$ \\
Total Jumlah Spesies Ikan Karang & $112(6)$ & $102(6)$ & $78(6)$ & $137(6)$ \\
Total Spesies Ikan Chaetodontidae & $6(4)$ & $8(4)$ & $7(4)$ & $15(6)$ \\
\hline \multirow{2}{*}{ Nilai Komulatif } & 34 & 34 & 34 & 36 \\
& Tinggi & Tinggi & Tinggi & Tinggi \\
\hline
\end{tabular}




\section{Status (Kondisi) Ikan Karang}

Hasil analisis nilai komulatif menunjukan status (kondisi) ikan karang antar stasiun terumbu karang di perairan pesisir Negeri Huikurila tergolong Tinggi (Tabel 6). Walaupun kondisi ikan karang pada terumbu ST1, ST2 dan ST3 tergolong tinggi, tetapi memiliki total spesies ikan Chatodontidae kategori moderat atau sedang. Hal ini berbeda dengan terumbu karang ST4 yang memiliki jumlah spesies dari famili Chaetodontidae dengan kategori tinggi yang termasuk lima parameter penilaian lainnya.

Tinggi dan rendahnya kelimpahan individu dan diversitas spesies ikan karang sangat bergantung pada kondisi terumbu karang sebagai habitat hidupnya (Sahetapy dan Matakupan, 2010; Huliselan et al., 2018; Sahetapy et al., 2019). Status ikan karang dengan nilai kumulatif tinggi pada empat stasiun terumbu karang Negeri Hukurila dipengaruhi oleh kompleksitas habitat terumbu karang (Hukom dan Retraubun, 2008), kondisi terumbu karang termasuk kategori baik hingga sangat baik (Sahetapy dan Far-Far, 2008; Sahetapy et al., 2019), dengan nilai persen penutupan karang batu tinggi dan variasi spesies karang batu kriteria relatif tinggi.

\section{KESIMPULAN DAN SARAN}

\section{Kesimpulan}

Terumbu karang Negeri Hukurila memiliki 192 spesies ikan karang dari 78 genera dan 26 famili, terdiri atas 71 spesies target, 103 spesies major, 18 spesies indikator, dan dua spesies endemik (Neoglyphidodon crossi, Cirrhilabrus solorensis). Famili Pomacentridae, Labridae, Chaetodontidae, Acanthuridae dan Serranidae memiliki kekayaan spesies tinggi. Diversitas relatif ikan karang termasuk kategori poor hingga moderate, dan diestimasi jumlah spesies ikan karang yang harus berada di terumbu karang ini sebanyak 369 spesies. Keragaman spesies ikan karang tinggi, dengan dominansi spesies rendah di dalam komunitas, dan keserasian spesies ikan karang berada dalam kondisi stabil. Densitas, sediaan cadang
DOI: https://doi.org/10.30598/TRITONvol15issue2page46-57

dan potensi ikan karang termasuk kriteria sedang. Secara spasial, densitas, sediaan cadang dan potensi ikan karang di terumbu karang ST4 termasuk kriteria tinggi, dan rendah pada terumbu karang ST3. Status (kondisi) ikan karang pada areal terumbu karang Negeri Hukurila tergolong tinggi.

\section{Saran}

Disarankan agar Dinas Perikanan dan Dinas Pariwisata Kota Ambon bersama Pemerintah dan Lembaga Kewang Negeri Hukurila melakukan pengawasan ketat terhadap pemanfaatan lahan pesisir, sumberdaya ikan karang dan aktivitas wisata bahari di areal terumbu karang agar tidak berdampak negatif terhadap kualitas terumbu karang dan eksitensi sumberdaya ikan karang.

\section{UCAPAN TERIMAKASIH}

Artikel ini ditulis atas ijin penggunaan data Kajian Kelayakan Pengembangan Pariwisata di Negeri Hukurila, yang dibiayai Pemda Kota Ambon. Ucapan terima kasih juga disampaikan kepada mereka yang dengan rela telah mereview artikel ini.

\section{DAFTAR PUSTAKA}

Allen, G.R. 2000. Marine Fishes of South-East Asia, A field guide for anglers and divers. Periplus Editions (HK) Ltd: Western Australia Museum $292 \mathrm{p}$.

Allen, G.R. 1998. Reef and shore fishes of Milne Bay Province, Papua New Guinea. In A rapid Biodiversity Assessment of The Coral Reefs of Milne Bay Province, Papua New Guinea. Werner TB and Allen GR (eds), RAP Working Papers 11, Conservation International, Washington, DC 39-49, 67-107.

Allen, G.R \& M. Adrim. 2003. Review Article: Coral reef fishes of Indonesia. Zoological Studies 42(1): pp. 1-72.

Allen, G.R \& M.V. Erdmann. 2012. Reef Fishes of the East Indies Vol I-II. Tropical reef research, Perth, Australia in Cooperation with Conservation Indonesia, Indonesia Marine Program, Denpasar Indonesia 1292 p. 
Allen, G.R \& R. Steene. 2002. Indo Pascific Coral Reef, Field Guid. Tropical Reef Research: 378 $\mathrm{p}$.

Allen, G.R, R. Steen, P, Humann, N. Deloach. 2003. Reef Fish Identification Tropical Pacific. Florida USA: New World Publications, Inc $457 \mathrm{p}$.

Amesbury, S.S, D. Sahetapy, S. Wouthuyzen, M. Adrim. 1982. Preliminary Assesment of Stocks of Economically Valuable Foodfish in Ambon Bay, Indonesia. University of Guam Press: 25 p.

Amesbury, S.S. \& R.F. Myers, 1982. The Fishes, Guide to the Coastal Resources of Guan Vol. I. University of Guam Press $141 \mathrm{p}$.

Bengen, D.G. 2013. Bio-ekologi Terumbu Karang, Status dan Tantangan Pengelolaan. Coral Governance: Skretariat Nasional CTI-CFF Indonesia. IPB Press: 61-74.

Chou, L.M. 2000. Southeast Asia reef-status update: Cambodia, Indonesia, Malaysia, Philippines, Singapore, Thailand and Vietnam. In Wilkinson C Status of coral Reefs of the World, CORDIO 117-129.

Critic Coremap. (2005). Coremap Phase II, Reef health indicator: Basic, Intermediate and Advanced level Standard Operations Procedure, Critic Coremap II (53): 54.

English S., C. Wilkinson and V. Baker. 1997. Survey Manual for Tropical Marine Resources. ASEAN-Australia Marine Science Project: Living Coastal Resources. Australian Institute of Marine Science, Townsville, Australia: $368 \mathrm{p}$.

Giyanto, M. Abrar, T.A. Hadi, A. Budiyanto, M. Hafizt, A. Salatalohy, M.Y. Iswari. 2017. Status Terumbu Karang Indonesia 2007. COREMAP-CTI, Pusat Penelitian Oseanografi- LIPI : 30 hal, ISBN 978-6026664-09-9.

Green, A. L. \& Mous, P. J. 2008. Delineating the Coral Triangle, its Ecoregions and Functional Seascapes. Version 5.0. TNC Coral Triangle Prog. Rep. p 44.

Halford, A. 2002. Reef fish biodiversity of Banda Island, Eastern Indonesia. In Report on Rapid Ecological Assessment of the Banda Islands, Maluku, Eastern Indonesia. The Natur Conservancy, Sanur Bali Indonesia 78-87.

Heemstra, P.C \& J.E. Randall. 1993. Grouper of the World (Family Serranidae, Subfamily Epinephelinae. FAO Species Catalogue $6(125) 424 \mathrm{p}$.
Hukom, F.D. 2010. Biodiversitas dan kondisi ikan karang pada beberapa lokasi perairan terumbu karang Kabupaten Flores Timur, Provinsi Nusa Tenggara Timur. Prosiding Seminar Nasional Biologi, Fakultas Biologi Universitas Gajah Mada Press: 200-221.

Hukom, F.D \& A.S.W. Retraubun. 2008. Potensi Sumberdaya Ikan Karang dan Objek Wisata Laut Pada Perairan Pulau-Pulau Terluar Provinsi Papua. Proceeding Konferensi Nasional II: Pengelolaan Sumberaya Pesisir Laut. Kementerian Kelautan dan Perikanan Republik Indonesia, Press : hal. 938-947.

Huliselan, N.V., D. Sahetapy, M.A. Tuapattinaja, M. Wawo. 2019. Community structure of target reef fish at four tiny islands coral reef in inner Kotania bay, Maluku Province, Indonesia. IOP Conf. Series: Earth and Environmental Science (EEC) $339 \quad$ (2019) 012005 doi:10.1088/1755-1315/339/1/012015: 8 p.

Huliselan, N.V., M. Wawo. M.A. Tuapattimiaja, D. Sahetapy. 2018. Economically Food Fish at Coral Reef of Kotania Bay, Western Seram Regency, Maluku Province Indonesia. International Journal of Fisheries and Aquatic Studies 6(2): pp. 105-109.

Kuiter, R.H. 1992. Tropical Reef-Fishes of The Western Pacific Indonesia and Adjacent Waters. PT. Gramedia Pustaka Utama, Jakarta:314 p.

Kuiter, R. H and T. Tanozuka. 2001. Pictorial Gude to Indonesian Reef fishes Part 1 Muraenidae to Lutjanidae. Australia: Zoonetics www.zoonetics.com: 302 p.

Lieske, E \& R. Myers. 1995. Coral reef Fishes, Indo-Pacific and Carribean, Collins Pocket Guide: $400 \mathrm{p}$

Limmon, GV, Khouw AS, Loupatty SV, Rijoly F, Pattikawa JA. 2017b. Species richness of reef food fishes in Ambon Island waters, Maluku Province, Indonesia. AACL Bioflux 10(3): pp. 507-511.

Limmon, GV, Rijoly F, Ongkers OTS, Loupatty SR, Pattikawa, JA. 2017a. Reef fish in the southern coastal waters of Ambon Island, Maluku Province, Indonesia. AACL Bioflux 10(2): pp. 234-240.

Lowe-McConnell, R.H. 1987. Ecological Studies in Tropical Fish Communities. Campbridge University Press: pp. 177 - 210.

Manuputty, J. 2008. Eksplorasi terumbu Karang di Perairan Pesisir Desa Leahari, Kecamatan Leitimur Selatan. Skripsi. Fakultas Perikanan 
dan Ilmu Kelautan Universitas Pattimura (Tidak Diterbitkan).

Manuputty, AEW \& Winardi. 2007. Wakatobi Monitoring Ekologi Wakatobi. COREMAP Phase II. Lembaga Ilmu Pengetahuan Indonesia Press: 35 hal.

Muljadi, A.H \& F. Rijoly. 2013. The diversity of reef fish in the Banda Islands. In Marine rapid assessment of the Banda Islands, Central Maluku Regency, Indonesia. Coral Triangle Center Press: pp. 88-97.

Odum, E.P. 1975. Ecology. The Link Between the Natural and the Social Science. Second Edition. Rinehart and Winston : pp. 53-56.

Odum, E.P. 1971. Fundamental of Ecology. W.B. Sounders, Philadelphia.

Peristiwady, T. 2006. Ikan-Ikan Laut Ekonomis Penting di Indonesia, Panduan Idendifikasi. Lembaga Ilmu Pengetahuan Indonesia Press: 270 hal.

Rijoli, F. 2006. Potensi Ikan Karang di Perairan Pesisir Desa Rutong dan Perairan Sekitarnya. Prosiding Seminar: Potensi dan Peluang Pengembangan Sumberdaya Pesisir Desa Rutong. Fakultas Perikanan dan Ilmu Kelautan Universitas Pattimura Press: hal 164-179.

Rijoly, F. 2015. Potensi dan Diversitas Ikan Karang di Laut Banda. Paper dipresentasikan pada Seminar Nasional: Pengembangan Kelautan dan Perikanan Berbasis Laut Banda, 25-26 Mei 2015.

Sahetapy D., A.S.W. Retraubun, D.G. Bengen., J. Abrahamsz. 2018. Coral reef fishes of Tuhaha Bay, Saparua Island, Maluku Province Indonesia. International Journal of Fisheries and Aquatic Studies (IJFAS) 6(2): pp. 105109.

Sahetapy D., A.S.W. Retraubun, D.G. Bengen., J. Abrahamsz. 2019. Potency of Reef Fishes in
DOI: https://doi.org/10.30598/TRITONvol15issue2page46-57

Tuhaha Bay Waters, Central Maluku Regency, Maluku Province Indonesia. IOP Conf. Series: Earth and Environmental Science (EEC) $339 \quad$ (2019) 012005 doi:10.1088/1755-1315/339/1/012006 : $10 \mathrm{p}$

Sahetapy, D. \& H. Matakupan. 2010. Potensi Sumberdaya Ikan Karang di Terumbu Karang Pulau-Pulau Kecil Kabupaten Seram Bagian Timur, Provinsi Maluku. Prosiding Komperensi Nasional VIII: Pengelolaan Sumberdaya Laut, Pesisir dan Pulau-Pulau Kecil. Kementerian Kelautan Dan Perikanan R.I. Press.

Sahetapy, D. \& R. Far-Far. 2008. Kondisi Terumbu Karang di Perairan Pesisir Pulau-Pulau Kecil Kecamatan Gorom, Kabupaten Seram Bagian Timur, Provinsi Maluku. Proceeding Konferensi Nasional VII: Pengelolaan Sumberdaya Pesisir and Laut. Kementerian Kelautan dan Perikanan R.I, Press: hal. 474 485.

Veron, J.E.N., De Vantier L.M., Turak E., Green, A.L., Kininmonth S., Stafford Smith, M., Petersen N. 2009. 'Delineating the Coral Triangle'. Galexea, Journal of Coral Reef Studies 11: pp. 91-100.

White, W.T, P.R. Last, Dharmadi, R. Faisah, U. Chodijah, B.I. Prisantoso, J.J. Fogonoski, M. Puckridge, S.J.M. Blaber. 2013. Market Fishes of Indonesia. Australian Centre for International Agricultural Research 437 p.

Wouthuyezen, S., F.D. Hukom, P. Makatipu, D. Pelasula. 2018. Reef fish stocks assessment around the islands in the Banda Sea for supporting local community livelihood. International Symphosium on Banda Sea Ecosystem. IOP Conf. Series: Earth and Environmental Science 184 (2018) 012009. Open Access: 21p. 